\title{
Pelatihan Pelaporan Keuangan Sederhana dan Manajemen Keuangan Bagi UMKM yang Terdaftar di Bank Wakaf Mikro UNISA
}

\author{
* Rigel Nurul Fathah, Teti Anggita Safitri \\ Fakultas Ilmu Ekonomi Sosial dan Humaniora Universitas Aisyiyah Yogyakarta, Indonesia \\ Jl. Siliwangi No 63 Mlangi Nogotirto Gamping Sleman \\ *Email: rigelnurul@unisayogya.ac.id
}

DOI: https://doi.org/10.21107/pangabdhi.v6i2.7538

Naskah diterima 14 Juni 2020, Revisi 28 Juli 2020, Terbit 29 Oktober 2020

\begin{abstract}
A business both small and large scale requires good financial management. The potential of UMKM so far, has not been sufficiently exploited to the maximum, on the contrary many MSME actors (owners) actually often experience internal problems making it difficult to develop and compete both among MSMEs and with large producers. The problem of financial management is one of the problems that is often encountered in MSMEs. Financial management and financial management are important aspects for the progress of MSMEs. Financial management can be done through accounting. Accounting is a systematic process to produce financial information that can be used for decision making for its users. The proposed Community Service Program is to provide MSME financial training, specifically regarding standardized and simple financial management, along with the process of socialization and assistance to MSMEs and financial management. Centralized training conducted is training on simple financial management methods and MSME financial management. The output of this program is that MSME practitioners gain knowledge of simple financial reporting and financial management.
\end{abstract}

Key Words: small business, financial management, community services

\section{PENDAHULUAN}

Usaha Mikro Kecil Menegah (UMKM) merupakan kelompok usaha yang memiliki jumlah paling besar dalam perekonomian Indonesia yang bermodalkan kurang lebih atau sama dengan Rp 200.000.000. Pada tahun 2018, jumlah UMKM di seluruh Indonesia mencapai 58,97 juta dengan kontribusi kepada PDB sebesar 30\%. UMKM merupakan sektor usaha yang paling banyak menyerap tenaga kerja di Indonesia hingga mencapai $97 \%$ tenaga kerja Indonesia (Fathah, 2020). Kegiatan Usaha Mikro, Kecil, dan Menengah (UMKM) merupakan salah satu bidang usaha yang dapat berkembang dan konsisten dalam perekonomian nasional.

UMKM menjadi wadah yang baik bagi penciptaan lapangan pekerjaan yang produktif. (Ananda, 2017). Undang-Undang Nomor 20 tahun 2008 menetapkan bahwa UMKM adalah usaha perdagangan yang dikelola badan usaha atau perorangan yang merujuk pada usaha ekonomi produktif. UMKM sampai sejauh ini belum memaksimalkan potensinya dan belum tergarap dengan baik. Permasalahan internal yang sering dihadapi pelaku kegiatan UMKM (pemilik) mengakibatkan bisnis yang dijalankan sulit untuk berkembang dan bersaing dengan sesama UMKM. Permasalahan pengelolaan keuangan merupakan salah satu kendala yang sering ditemukan pada UMKM. Banyak pelaku kegiatan UMKM memulai usahanya hanya dengan bermodalkan niat dan nekat tanpa memikirkan rencana jangka panjang dan keberlanjutan usahanya. Perencanaan permodalan jangka panjang, kemampuan dan pengetahuan manajerial, serta pengetahuan pelaporan keuangan sangat dibutuhkan dalam berwirausaha (Undang-Undang Nomor 20 Tahun 2008)

Program pengembangan UMKM sebagai salah satu instrument untuk menaikkan daya beli masyarajar pada akhirnya akan menjadi katup pengaman dari situasi krisis moneter. Pengembangan UMKM menjadi sangat strategis dalam menggerakkan perekeonomian nasional, mengingat kegiatan usahanya mencakup hampir semua lapangan usaha, sehingga kontribusi UMKM menjadi dangat besar bagi peningkatan pendapatan bagi kelompok masyarakat 
berpendapatan rendah (Anggraeni, 2016)

Praktek manajemen pada UMKM sebagian besar masih menganut pola manajemen tradisional karena beberapa sebab antara lain (Fathah, 2020):

1. UMKM yang tumbuh dan berkembang di Indonesia lebih banyak dikelola oleh perorangan (one man show) atau pun dikelola oleh satu keluarga yang berpegang teguh pada suatu tradisi pengelolaan usaha.

2. Banyak pelaku UMKM yang masih awam dan enggan untuk memikirkan hal rumit seperti manajemen keuangan dan akuntansi sehingga berakibat pada sistem akuntansi yang buruk dan menjadikan UMKM tersebut sulit berkembang.

3. Pola permintaan konsumen yang relatif tidak banyak berubah (oleh karena minimnya kompetensi).

4. Teknologi dalam penggunaan alat bantu proses dan produksi masih sederhana

Keberhasilan dan kemajuan UMKM tidak lepas dari salah satu aspek penting yaitu pengelolaan keuangan yang baik. Peran akuntasi dapat mendukung pengelolaan keuangan pada UMKM. Akuntansi merupakan proses sistematis untuk menghasilkan informasi keuangan yang dapat digunakan untuk pengambilan keputusan bagi penggunanya. Sepanjang UMKM masih menggunakan uang sebagai alat tukarnya, akuntansi sangat dibutuhkan oleh UMKM. Akuntansi akan memberikan beberapa manfaat bagi pelaku UMKM, antara lain (Farwitawati, 2018) : (1) UMKM dapat mengetahui kinerja keuangan perusahaan, (2) UMKM dapat mengetahui, memilah, dan membedakan harta perusahaan dan harta pemilik, (3) UMKM dapat mengetahui posisi dana baik sumber maupun penggunaannya, (4) UMKM dapat membuat anggaran yang tepat, (5) UMKM dapat menghitung pajak, dan (6) UMKM dapat mengetahui aliran uang tunai selama periode tertentu. Melihat manfaat yang dihasilkan akuntansi, pelaku UMKM seharusnya sadar bahwa akuntansi penting bagi perusahaan mereka. Penggunaan akuntansi dapat mendukung kemajuan UMKM khususnya dalam hal keuangan. Peningkatan laba juga dapat direncanakan dengan menggunakan akuntansi.

Dengan tingkat laba yang semakin meningkat, perkembangan UMKM akan menjadi lebih baik sehingga UMKM akan benar-benar menjadi salah satu solusi bagi masalah perekonomian di Indonesia. Namun, masih banyak UMKM yang belum menggunakan akuntansi dalam menunjang kegiatan bisnisnya. Alasan pelaku UMKM tidak menggunakan akuntansi antara lain adalah akuntansi dianggap sesuatu yang sulit dan tidak penting. (Setyorini et.al, 2012).

Potensi berkembangnya UMKM di Indonesia tidak lepas dari dukungan perbankan dalam penyaluran kredit kepada UMKM. Menurut data Bank Indonesia, setiap tahunnya kredit kepada UMKM mengalami pertumbuhan (Amalia, 2020). Bank Wakaf Mikro Lembaga Keuangan Mikro Syariah (BWM LKMS) UNISA diluncurkan pada 3 Agustus 2018. BWM LKMS UNISA merupakan program kerjasama PPA dan OJK yang dijalankan oleh Universitas 'Aisyiyah (UNISA) Yogyakarta yang terletak di Nogotirto Gamping Sleman.

Ketua BWM LKMS mengatakan pada tahap pertama sudah terkumpul 25 perempuan pengusaha mikro untuk diberikan modal. Usaha yang dijalankan beragam seperti toko kelontong, warung makan, laundry, pedagang pasar, dan penyetor pakaian batik di Malioboro. Sebagian besar pelaku usaha mikro yang terdaftar di BWM LKMS UNISA ini belum melakukan pencatatan dan penyusunan laporan keuangan secara baik dan benar. Sebagian besar mereka hanya mencatat penerimaan dan pemasukan saja selebihnya tidak melakukan pencatatan keuangan.

Beberapa masalah pengelolaan keuangan umum yang sering dijumpai pada UMKM antara lain adalah:

1. Kurangnya pengetahuan manajemen keuangan oleh para pelaku UMKM, yaitu masih tercampurnya keuangan pribadi pemilik dengan keuangan usaha.

2. Penentuan harga produk sering dilakukan secara sederhana dan intuitif, tanpa menghitung biaya yang telah dikeluarkan secara cermat.

3. Kurangnya pengetahuan mengenai pencatatan keuangan dan pengelolaan keuangan

Dari berbagai masalah tersebut, yang menjadi masalah utama adalah kurangnya kemampuan pengelolaan keuangan yang dimiliki para pelaku usaha mikro kecil dan menengah. Program pelatihan yang ditawarkan berupa pelatihan pelaporan keuangan sederhana bagi UMKM.

\section{METODE}

Dari permasalahan - permasalahan mitra yang telah disebutkan diatas, maka pengabdian ini memiliki program yang diharapkan dapat menjadi solusi bagi permasalahan yang dialami oleh mitra dengan beberapa metode, yaitu : 
1. Metode Ceramah yaitu memberikan Pendidikan dan arahan yang cukup mengenai pembukuan dan pelaporan keuangan yang sederhana bagi UMKM sehingga bisa diterapkan dalam menjalankan usaha.

2. Metode Pelatihan dengan memberikan Pendidikan singkat tentang pelaporan keuangan sederhana dan manajemen keuangan. Mitra diharapkan mengetahui posisi keuangan dan mengontrol modal yang dikeluarkan untuk mengola usaha dan berapa besar pendapatan yang mereka peroleh.

Adapun target pelatihan antara lain: (1) Memberikan pembekalan dan motivasi kepada anggota pelaku usaha mikro yang terdaftar di BWM LKMS Unisa agar memiliki kemauan untuk menggunakan akuntansi dalam kegiatan usahanya. Selain itu peserta diberikan materi gambaran umum tentang akuntansi UMKM dan peran penting akuntansi bagi UMKM; (2) Menambah pengetahuan dengan memberikan materi berisi pencatatan dan pelaporan keuangan akuntansi serta literasi keuangan keluarga.

Sumber daya manusia yang terlibat dalam kegiatan ini adalah dosen yang memiliki kepakaran untuk menyelesaikan persoalan mitra dan mahasiswa yang membantu aspek teknis. Berikut disajikan dalam tabel adalah kepakaran masing-masing dosen yang tertuang dalam bentuk tugas dan kewajiban.

\section{HASIL DAN PEMBAHASAN}

Kegiatan PKM dimulai dengan wawancara dengan ketua BWM LKMS UNISA dan mengumpulkan informasi terkait nasabah pelaku UMKM yang terdaftar di LKMS BWM UNISA tersebut. Setelah itu, dilakukan survey ke lokasi usaha oleh mahasiswa. Dari hasil survey diketahui bawa nasabah yang terdaftar di lembaga tersebut dikelompokkan menjadi beberapa kelompok pemberdayaan yang dinamakan Silaturahmi Mingguan (Silmi).

Dari beberapa Silmi, diperoleh informasi bahwa selama ini mereka belum cukup memiliki pemahaman terhadap pentingnya manajemen keuangan dalam penyusunan laporan keuangan usaha. Pemasukan dan pengeluaran uang tidak dicatat dengan semestinya dan tidak dipisahkan dengan keuangan keluarga. Beberapa pelaku usaha hanya mengumpulkan nota pengeluaran sebagai bukti untuk kas (uang) yang sudah dikeluarkan. Sedangkan untuk pemasukan hanya menghitung fisik uang yang sudah diterima atau akumulasi besaran rupiah sesuai pesanan yang diterima.
Perhitungan yang dilakukan para pelaku usaha mikro belum terperinci dan ketika ditanyakan berapa omset perbulannya mayoritas dari mereka tidak bisa menjawab pertanyaan tersebut. Dari hasil survey dan wawancara tersebut maka tim pengabdian bekerjasama dengan mitra dalam hal ini LKMS BWM UNISA untuk melaksanakan pengabdian dalam bentuk pelatihan. Selain itu para peserta juga diberikan pemahaman pentingnya manajemen keuangan usaha dan pemisahan keuangan usaha dengan keluarga. Dengan diadakan pelatihan ini diharapkan dapat membantu permasalahan yang dihadapi para pelaku usaha dalam melakukan pembukuan usaha.
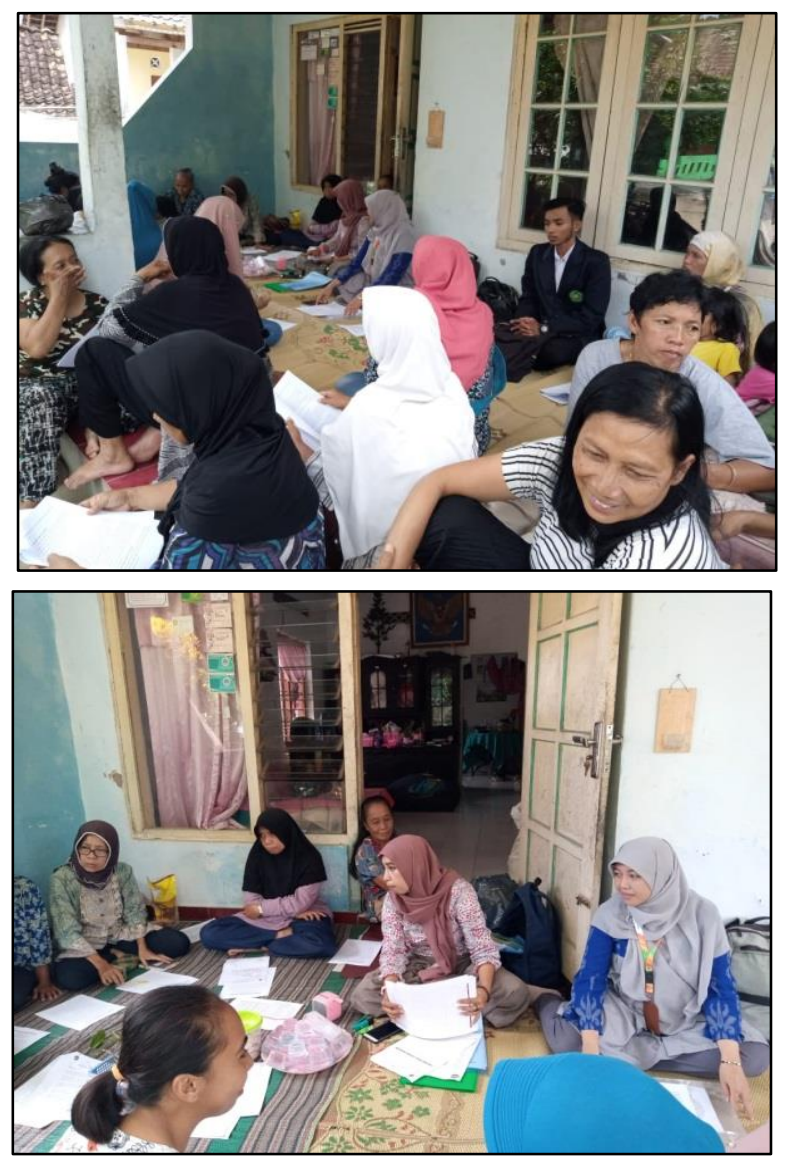

Gambar 1. Pelaksanaan Kegiatan Pengabdian Masyarakat 
Tabel 1. Tanggapan Peserta terhadap Kegiatan Pelatihan

\begin{tabular}{|l|l|l|l|l|l|}
\hline No & Keterangan & Sangat Setuju & Setuju & Tidak Setuju & Sangat Tidak Setuju \\
\hline 1 & $\begin{array}{l}\text { Saya sangat antusias dan } \\
\text { semangat mengikuti } \\
\text { pelatihan ini }\end{array}$ & $18,75 \%$ & - & - \\
\hline 2 & $\begin{array}{l}\text { Pelatihan ini menurut saya } \\
\text { sangat penting dilakukan }\end{array}$ & $100 \%$ & - & - & - \\
\hline 3 & $\begin{array}{l}\text { Pelatihan ini menambah } \\
\text { pengetahuan bagi saya }\end{array}$ & $87,5 \%$ & $12,5 \%$ & - & - \\
\hline
\end{tabular}

Tabel 2. Tanggapan Peserta Terhadap Materi

\begin{tabular}{|l|l|l|l|l|l|}
\hline No. & Keterangan & Sangat Setuju & Setuju & Tidak Setuju & Sangat Tidak Setuju \\
\hline 1. & $\begin{array}{l}\text { Pelatihan ini menambah } \\
\text { ketrampilan bagi saya }\end{array}$ & $75 \%$ & $25 \%$ & - & - \\
\hline 2. & $\begin{array}{l}\text { Pelatihan ini dapat } \\
\text { menumbuhkan minat } \\
\text { kewirausahaan bagi saya }\end{array}$ & $87,5 \%$ & $12,5 \%$ & - & - \\
\hline 3 & $\begin{array}{l}\text { Tim Pengabdian telah } \\
\text { memberikan pelatihan ini } \\
\text { dengan sangat jelas }\end{array}$ & $68,75 \%$ & $31,25 \%$ & & \\
\hline
\end{tabular}

Tabel 3. Tanggapan Peserta Terhadap Hasil Kegiatan Pelatihan

\begin{tabular}{|l|l|l|l|l|l|}
\hline No. & Keterangan & Sangat Setuju & Setuju & Tidak Setuju & Sangat Tidak Setuju \\
\hline 1. & $\begin{array}{l}\text { Setelah pelatihan ini, saya } \\
\text { bisa mengaplikasikan } \\
\text { pembuatan laporan } \\
\text { keuangan keluarga dan } \\
\text { usaha }\end{array}$ & $25 \%$ & - & - \\
\hline 2. & $\begin{array}{l}\text { Setelah pelatihan ini, saya } \\
\text { akan menerapkan dan } \\
\text { mengaplikasikan di usaha } \\
\text { saya }\end{array}$ & $12,5 \%$ & - & \\
\hline
\end{tabular}

Tim pengabdian telah melaksanakan kegiatan pelatihan pelaporan keuangan sederhana bersama mitra dan para pelaku UMKM yang terdaftar sebagai nasabah mitra.

a. Tahap Persiapan Pelatihan

Dari hasil wawancara dan survey serta koordinasi dengan mitra maupun pelaku UMKM di lapangan, tim pengabdian mulai menyiapkan materi yang akan disampaikan pada peserta. Tim pengabdian juga berkoordinasi dengan mitra untuk mengumpulkan peserta. Materi yang disampaikan antara lain : a) Pentingnya Pencatatan Keuangan Usaha b) Pembukuan Keuangan Sederhana c) Tata Kelola Keuangan d) Manajemen Keuangan Pemisahan Keuangan Keluarga dan Usaha Kegiatan. Pelatihan ini dilaksanakan di Universitas Aisyiyah Yogyakarta ruang B.305

b. Tanggapan Peserta UMKM terhadap Kegiatan Pelatihan
Setelah diadakan pelatihan, para peserta dibagikan kuesioner. Jawaban peserta terlihat pada Tabel 1 hingga 3.

\section{KESIMPULAN}

Kegiatan pelatihan yang dicapai telah berhasil dilaksanakan dan materi telah disampaikan ke peserta tentang pentingnya pelaporan keuangan di kegiatan usaha serta manajemen keuangan UMKM. Kegiatan pelatihan Pelaporan Keuangan Sederhana Bagi UMKM dan Manajemen Keuangan sudah sesuai dengan tahapan-tahapan yang disusun dan terdapat peningkatan pemahaman, pengetahuan dan keterampilan dalam menyiapkan laporan keuangan usaha. Peserta sudah mampu memanfaatkan materi yang telah diberikan dan mampu menerapkan dan mengaplikasikannya dalam kegiatan usahanya. 


\section{DAFTAR PUSTAKA}

Amalia, D. 2020. Pengertian Jenis dan Perkembangan UMKM di Indonesia : http://www.jurnal.id/blog/pengertian-jenisdan perkembangan-umkm-di-indonesia.

Ananda, S. 2017. Pengembangan Usaha Mikro Kecil dan Menegah (UMKM) Berbasis Industri Kreatif di Kota Malang. Jurnal Ilmu Ekonomi. 120-142 pp.

Anggraeni, H. H. 2016. Pengembangan Usaha Mikro Kecil dan Menengah (UMKM) Melalui Fasilitas Pihak eksternal dan Potensi Internal (Studi Kasus pada Kelompok Usaha "Emping Jagung" di Kelurahan Pandanwangi Kecamatan Blimbing, Kota Malang). Jurnal Administrasi Publik. Vol 1.1286-1295 pp.
Farwitawati, R. 2018. Pengelolaan Keuangan Bagi Usaha Mikro Kecil Menengah (UMKM) di Kelurahan Air Putih Kecamatan Tampan Kota Pekanbaru. Sembadha. Vol 1(1). 225229 pp.

Fathah, R. W. 2020. Pelatihan Manajemen Keuangan Bagi Pelaku Usaha Mikro Kecil dan Menengah (UMKM) Di Sekitar UNISA. The 11th University Colloqium, 55-58.

Setyorini, I. N. 2012. Pelatihan Akuntansi UMKM Bagi Usaha Mikro Kecil Menengah Untuk Meningkatkan Kinerja Keuangan Perusahaan. Tidak dipublikasikan: Laporan Pengabdian Masyarakat .

Undang-Undang Nomor 20 Tahun 2008. (2008). Usaha Mikro Kecil dan Menengah. 